\title{
Ruch B Corp wobec wyzwań zrównoważonego rozwoju w dobie pandemii COVID-19 - wybrane polskie przykłady
}

\author{
B Corp Movement in the Face of Challenges of Sustainable Development in the COVID-19 \\ Pandemic. An Overview of Selected Polish Cases
}

\author{
Ewa Jastrzębska \\ Kolegium Ekonomiczno-Społeczne, Szkoła Główna Handlowa w Warszawie \\ ORCID: https://orcid.org/0000-0002-0029-6943• ewa.jastrzebska@sgh.waw.pl \\ Zgłoszono: 14.04.2021; zrecenzowano: 18.05.2021; zaakceptowano do druku: 24.05.2021
}

Streszczenie: Pandemia COVID-19 wywołała bezprecedensowe konsekwencje - począwszy od służby zdrowia, poprzez gospodarkę, aż do życia społeczeństw. Jej wielowymiarowy negatywny wpływ sprawił, że zdaniem wielu ekspertów pod znakiem zapytania stanęła realizacja Celów Zrównoważonego Rozwoju ONZ (SDGs). Panuje jednak coraz powszechniejsze przekonanie, że obecny kryzys to doskonała okazja, by projektując popandemiczną rzeczywistość, nie powielać błędów wcześniejszego modelu rozwoju. Kluczową rolę w tym zakresie powinien odegrać biznes, który ma do swojej dyspozycji różnorodne koncepcje, pokazujące jak odpowiedzialnie działać na rzecz otoczenia i budować zrównoważoną gospodarkę. Jedną z takich koncepcji jest ruch B Corporation. Celem artykułu jest próba odpowiedzi na pytanie, czy ruch B Corp przyczynia się do realizacji SDGs, szczególnie dotkniętych negatywnym wpływem pandemii, zarówno z punktu widzenia teorii (ocena założeń ruchu), jak i empirii (analiza wybranych polskich przykładów firm z certyfikatem B Corp). Tak postawionemu celowi podporządkowane zostały metody badawcze - krytyczna analiza literatury przedmiotu oraz studia przypadku. Przeprowadzone analizy pozwoliły stwierdzić, że założenia ruchu B Corp są zgodne z ideą zrównoważonego rozwoju, a B Corps w Polsce przyczyniają się do wdrażania tych SDGs, które są szczególnie ważne w dobie pandemii.

Słowa kluczowe: rozwój zrównoważony, Cele Zrównoważonego Rozwoju ONZ, SDGs, COVID-19, biznes, B Corporation, B Corp

\begin{abstract}
The COVID-19 pandemic has led to grave and unforeseen consequences, whether in healthcare, economies, or in the lives of societies. Its multidimensional adverse impact has, according to many experts, put the achievement of the UN Sustainable Development Goals (SDGs) at risk. Nevertheless, there is a deeply held conviction that the current crisis is creating an excellent opportunity, while designing a post-pandemic reality, of avoiding the pitfalls of the previous development model. The private sector has a key role to play as it is in a position to apply various concepts of how to act responsibly and build a sustainable economy. One of such concepts is the Benefit Corporation movement. The article seeks answers to the question of whether the B Corp idea is contributing to realization of Sustainable Development Goals (SDGs), particularly those affected by the pandemic. The author offers both a theoretical (assessment of the movement and its foundations) and empirical view (analysis of Selected Polish B Corp-certified companies). This goal is to be achieved by employed research methods: a critical analysis of the literature on the subject and case studies. The author's analyses reveal that the foundations of the B Corp movement are aligned with the sustainable development concept, and that Poland-based $B$ Corps are contributing to the implementation of those SDGs that are particularly relevant in the time of the pandemic.
\end{abstract}

Keywords: sustainable development, UN Sustainable Development Goals, SDGs, COVID-19, business, B Corporation, B Corp 


\section{Wstęp}

Pierwszy przypadek COVID-19 w Polsce potwierdzono 4 marca $2020 \mathrm{r}$. (Ministerstwo Zdrowia 2020). Po 5 miesiącach od czasu pojawienia się (w listopadzie 2019 r.) pierwszych przypadków tej zakaźnej choroby w chińskim Wuhan, WHO 1 marca 2020 r. ogłosiła pandemię koronawirusa (WHO 2020b). Do 5 marca 2021 r. na świecie odnotowano 115094614 przypadków zachorowań i 2560995 zgonów we wszystkich 223 państwach/obszarach/terytoriach świata (WHO 2021a).

Nieprzewidywalność wirusa SARS-CoV-2 spowodowała bezprecedensowe konsekwencje - od wyzwań na niespotykaną wcześniej skalę postawionych przed służbą zdrowia począwszy od obciążeń systemów opieki zdrowotnej (Amante and Balmer 2020), różnorodnych i długofalowych skutków choroby (Graves 2021), w tym neurologicznych (Zimmer 2021), kolejnych mutacji wirusa (ECDC 2021), w tym przeniesienie go na zwierzęta (WHO 2020a), poprzez wprowadzenie nadzwyczajnych ograniczeń (zalecenia dystansu społecznego, kwarantanna, zakaz zgromadzeń, zamknięcie szkół, zamknięcie granic, zamrożenie gospodarek, stany wyjątkowe) (Bremmer 2021), aż do wywołania recesji gospodarczej (gorszej niż kryzys 2008+, a porównywalnej do Wielkiego Kryzysu lat 3o. XX w.) (Mordecai and Schumacher 2020) i kryzysu społecznego (pogorszenie zdrowia psychicznego i samopoczucia) (Panchal et al. 2021), ale i przyspieszenia transformacji cyfrowej (praca zdalna, e-commerce, automatyzacja i robotyzacja) (de Castro Sobrosa Neto et al. 2020). Zdaniem wielu ekspertów pandemia COVID-19 będzie oznaczać spowolnienie, a nawet zawrócenie $\mathrm{z}$ drogi prowadzącej ku zrównoważonemu rozwojowi (ZR) (Patrick 2020; UNDESA 2020b). Zgodnie z najczęściej przytaczaną definicją z raportu Brundtland z 1987 r., ZR to taki rozwój, który zaspokaja potrzeby obecne, nie pozbawiając przyszłych pokoleń możliwości zaspokojenia ich potrzeb (WCED 1987, 43). Definicja ta stanowi rozwinięcie wąskiej interpretacji
ZR, który - jako odpowiedź przede wszystkim na kryzys ekologiczny - początkowo był rozumiany tylko w kategoriach ekorozwoju odrzucającego dychotomię pomiędzy środowiskiem a rozwojem (Lélé 1991). Można to zauważyć, chociażby analizując zasady Deklaracji Sztokholmskiej, przyjętej w 1972 r. podczas I Szczytu Ziemi (UN Conference on the Human Environment - UNCHE), które ograniczają się do kwestii środowiskowych (ONZ 1972, 4-5). Definicja Brundtland skupia się natomiast na sprawiedliwości wewnątrzgeneracyjnej (ograniczeniu spirali ubóstwa i nierówności) i międzygeneracyjnej (zapobiegnięcie nieodwracalnej degradacji środowiska, aby zachować usługi ekosystemów stanowiące podstawę do zaspokojenia potrzeb) (WCED 1987, p. xi-xii). Oznacza to zakotwiczenie ZR w trzech wzajemnie powiązanych filarach - ekonomicznym, społecznym i ekologicznym (Mensah and Casadevall 2019). Takie szerokie ujęcie zrównoważonego rozwoju zostało zaprezentowane szerokiej opinii publicznej na II Szczycie Ziemi (UN Conference on Environment and Development - UNCED) w Rio de Janeiro w 1992 r. (ONZ 1992).

Mając korzenie pragmatyczne, uniwersalna acz ogólnikowa (Hopwood et al. 2005) koncepcja ZR została zoperacjonalizowana w ramach globalnych planów działania, z których pierwszy - Agenda 21 - został przyjęty podczas II Szczytu Ziemi (ONZ 1992). Za sprawą ogłoszonych i cieszących się powszechnym zainteresowaniem Celów Zrównoważonego Rozwoju ONZ (UN Sustainable Development Goals - SDGs), stanowiących obecną agendę rozwojową, świat zaczął zdecydowanie podążać w kierunku ZR. SDGs wyraźnie pokazały, że wyzwania stojące przez ZR są globalne, bo dotyczą w równym stopniu wymiarów ekonomicznego, społecznego i ekologicznego oraz państw rozwiniętych i rozwijających się (ONZ 2015). Tymczasem krótkofalowe skutki pandemii bezpośrednio dotknęły SDGs związane z wymiarem ekonomicznym (np. podstawowa kwestia utraty pracy i dochodów) czy społecznym (jakość życia), 
a także środowiskowym (z jednej strony wzrost wyrzucanych jednorazowych środków ochronnych, z drugiej ograniczenie emisji zanieczyszczeń w związku z gospodarczym lockdownem) (Chriscaden 2020).

COVID-19, jako jedna z chorób odzwierzęcych, pokazał jak katastrofalne skutki może mieć nadmierna ingerencja człowieka w środowisko przyrodnicze (The Lancet 2021, 71). Stworzył zarazem doskonałą okazję, by popandemiczną rzeczywistość zaprojektować zupełnie na nowo (Yunus 2020), wyciągając wnioski z popełnionych wcześniej błędów, zmieniając błędne zachowania i szkodliwe nawyki, redefiniując biznesowe priorytety (Deloitte 2020), budując zrównoważoną gospodarkę (OECD 2020). Do głównych sprawców generujących negatywne efekty zewnętrzne należy biznes, dlatego też - wraz z szacunkami wielowymiarowych skutków pandemii - coraz głośniej postuluje się konieczność resetu obecnego modelu rozwoju na bardziej włączający, a gospodarkę - na regeneratywną (Green Recovery Alliance 2020). Jedną z koncepcji, która zakłada odpowiedzialny sposób prowadzenia biznesu, jest ruch B Corporation (B Corp).

Celem artykułu jest próba odpowiedzi na pytanie, czy ruch B Corp przyczynia się do realizacji SDGs, szczególnie dotkniętych negatywnym wpływem pandemii COVID-19, zarówno z punktu widzenia teorii (ocena założeń ruchu), jak i empirii (analiza wybranych polskich przykładów firm z certyfikatem B Corp). Tak postawionemu celowi podporządkowane zostały metody badawcze - krytyczna analiza literatury przedmiotu oraz studia przypadku.

\section{Wpływ pandemii COVID-19 na realizowanie SDGs}

Trwająca pandemia COVID-19 sprawia, że trudno precyzyjnie oszacować jej wielowymiarowe konsekwencje dla rozwoju, zwłaszcza że są one bezpośrednie i pośrednie i ze sobą wzajemnie powiązane (np. utrata pracy, pociągająca za sobą spadek dochodów gospodarstw domowych, ogranicza konsumpcję, zmuszając firmy do zmniejszenia produkcji, uderzając tym samym w ich pracowników i cały łańcuch dostaw) (Copenhagen Economics 2020). Program Narodów Zjednoczonych ds. Rozwoju (United Nations Development Programme, UNDP) spodziewa się, że po raz pierwszy od momentu opracowania HDI w 1990 r., wskaźnik ten może spaść. Żaden z wcześniejszych kryzysów nie dotknął równocześnie wszystkich trzech aspektów HDI, tj. zdrowia, dochodów i edukacji (CCSA 2020, 38-39).

Dominuje powszechne przekonanie, że pandemia generalnie wpłynie negatywnie na ZR. Eksperci są zgodni, że największy negatywny wpływ COVID-19 wywrze na SDGs związane z ubóstwem (cel 1.), dobrym zdrowiem i jakością życia (3.), wzrostem gospodarczym i godną pracą (8.) oraz nierównościami (10.). Nieco rzadziej wskazuje się na cele dotyczące dobrej jakości edukacji (4.) oraz nierówności płci (5.) (UNDESA 202ob; UNIDO 2020a; UNSDG 2020; UNDP 2020; Sachs et al. 2020). Chociaż w tym ostatnim przypadku zdania są bardziej podzielone, to istnieje wiele dowodów przemawiających za tym, że pandemia COVID-19 pogłębia nierówności płci i dyskryminację oraz podatność na zagrożenia ze względu na płeć. Przyczynia się przez to do wzrostu przemocy wobec kobiet (EIGE 2021) i jeszcze większego obciążenia obowiązkami domowymi i opiekuńczymi (UNDP 2020, 3) oraz większego narażenia na utratę pracy i dochodów, a także wynikające z tego zaburzenia psychiczne i emocjonalne (Koprowska 2020).

Warto zauważyć, że dostrzega się także pozytywny wpływ pandemii w odniesieniu do celu dotyczącego partnerstwa na rzecz celów (17.), bo w dobie pandemii licznie zawiązywane są różne formy współpracy wychodzące naprzeciw pojawiającym się wyzwaniom (np. w zakresie opracowania szczepionki czy produkcji potrzebnego sprzętu) (Hiscott et al. 202o), a także celu dotyczącego działań w dziedzinie klimatu (13.) (chociaż tutaj uważa się, że pozytywny efekt zmniejszenia emisji gazów 
cieplarnianych do atmosfery będzie krótkotrwały) (Reilly et al. 2021).

W tabeli 1. zaprezentowano SDGs najczęściej wskazywane przez ekspertów jako zagrożone przez pandemię COVID-19 wraz z wybranymi wskaźnikami ilustrującymi ten negatywny wpływ. Jak wynika z tabeli
1., szczególnie dotknięte przez pandemię zostały przede wszystkim te cele, które już wcześniej oceniane były jako realizowane w niewystarczającym stopniu (UNDESA 2020a).

Zrównoważony rozwój jest koncepcją globalną, proponującą nowy model rozwoju

Tab. 1. Cele Zrównoważonego Rozwoju ONZ (SDGs) w największym stopniu dotknięte negatywnym wpływem pandemii COVID-19 wraz z ilustrującymi ten wpływ wybranymi wskaźnikami

\author{
SDGs, na który \\ pandemia COVID-19 \\ wywiera szczególnie \\ Wskaźniki ilustrujące negatywny wpływ pandemii COVID-19 na SDGs
}

negatywny wpływ

1 koNec $\quad$ - wzrost 0 71-100 mln osób żyjących w skrajnym ubóstwie w latach 2020-2021 (prognoza)

- $40 \%$ populacji państw OECD nie ma wystarczających oszczędności, by bez pracy utrzymać się dłużej mition niż 3 miesiące ponad krajową granicą ubóstwa

27580

- ok. $265 \mathrm{mln}$ ludzi z państw o niskich i średnich dochodach będzie zagrożona brakiem

bezpieczeństwa żywnościowego do końca 2020 r. (prognoza)

3 Dobrezorowie $\quad$ do 6 marca 2021 r. odnotowano 115094614 przypadków zachorowań i 2560995 zgonów, przede wszystkim w obu Amerykach (51 279 955) i Europie (39 418 631)

- globalnie 35\% badanych boi się, a 65\% jest zaniepokojonych możliwością zachorowania na COVID-19

- ponad 90\% przypadków COVID-19 występuje na obszarach miejskich

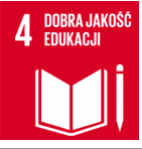

- w 57 państwach szkoły zostały całkiem zamknięte, ograniczając tym samym 681709287 uczniom dostęp do nauki i możliwości zdobycia kluczowych kompetencji społecznych

- 86\% uczniów szkół podstawowych w krajach rozwijających się nie ma dostępu do edukacji

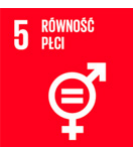

- wzrost liczby przypadków przemocy domowej zgłaszanych na infolinie organizacji pomocowych (np. we Francji 0 30\%, we Włoszech czterokrotnie, w Hiszpanii o prawie 70\% w pierwszym kwartale 2020 r.)

- wyższa zachorowalność na COVID-19 w służbie zdrowia wśród kobiet (np. kobiety stanowiły we Włoszech 66\%, w Hiszpanii 72\% zachorowań)

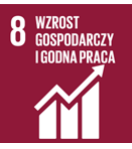

- w dwóch pierwszych kwartałach 2020 r. pracę w pełnym wymiarze czasu straciło 400 mln osób, przede wszystkim w krajach o niskich i średnich dochodach

- w kwietniu 2020 r. globalna produkcja przemysłowa spadła $020 \%$ w porównaniu do roku poprzedniego

- $60 \%$ państw doświadcza przedłużającego się spowolnienia gospodarczego

- wartość produkcji utraconej w skutek pandemii wyniesie 28 mld dolarów w ciągu najbliższych 5 lat (prognoza)

- spadek PKB 0 5-8\% w 2020 r. (prognoza)

- spadek globalnych BIZ 0 40\% w 2020 r. (prognoza)

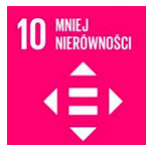

- 73 państwa w czasie pandemii mają częściowo lub całkowicie ograniczony dostęp do krajowych procedur azylowych

- do 6 marca 2021 r. na 249160837 dawek szczepionek 70454064 trafiło do Stanów Zjednoczonych Ameryki, a 21322717 do Wielkiej Brytanii

- wskaźnik dawek szczepionki przypadających na 100 osób wynosił w wybranych państwach: 31,4 w Wielka Brytania, 21,29 - USA, 3,57-Chiny, 3,12 - Brazylia, 0,2 - Australia, 0,17-Algieria, 0,12 - RPA Źródło: opracowanie własne na podstawie: CCSA 2020a; CCSA 202ob; Edelman 2021; FAO 2020; IMF 2020; The World Bank 2021; UNDESA 202ob; UNDP 2021; UNDP 2020; UNIDO 202ob; UNSDG 2020; WHO 2021b 
w miejsce wcześniejszego, skutkującego występującymi współcześnie negatywnymi megatrendami. Jego osiągnięcie jest zatem możliwe tylko dzięki współpracy różnych interesariuszy, w tym biznesu - z jednej strony sprawcy wielu problemów, z drugiej strony ze względu na swoją cywilizacyjnotwórczą rolę - interesariusza dysponującego możliwościami, by te problemy rozwiązać (Edelman 2021; UNGC 2013). Istnieje wiele koncepcji, które podpowiadają przedsiębiorstwom, jak maksymalizować swój wkład na rzecz ZR w skali mikro - obywatelstwo przedsiębiorstw (Crane et al. 2008), potrójna linia wyników (tripple bottom line) (Elkington 1997), społeczna odpowiedzialność biznesu (PKN 2012), tworzenie wspólnej wartości (Kramer and Porter 2011), turkusowe organizacje (Laloux 2015). Jedną z nich jest ruch B Corporation.

\section{Ruch B Corp jako wkład na rzecz zrównoważonego rozwoju}

Ruch B Corporation narodził się w 2006 r. na gruncie przekonania, że z wyzwaniami współczesnego świata nie mogą się mierzyć tylko rządy i organizacje pozarządowe. B Corps to firmy, które działają na rzecz zmniejszenia ubóstwa i nierówności, budowania silniejszych społeczności, zapewnienia czystego środowiska oraz tworzenia godnych miejsc pracy. Firmy te wykorzystują biznes do czynienia dobra („using business as a force for good") (B Lab 2021a). Generowane w ramach prowadzonego biznesu zyski B Corporations traktują jako środek do osiągnięcia większego celu: pozytywnego wpływu na pracowników, społeczności, środowisko i klientów. B Corps redefiniują sukces w biznesie i działają na rzecz bardziej integracyjnej i zrównoważonej gospodarki. Wartości społeczności B Corp określa Deklaracja Współzależności (Declaration of Interdependence) (B Lab 2021b).

Certyfikacja B Corporation oznacza, że firma spełnia wysokie standardy w zakresie całościowych wyników społecznych i środowiskowych, przejrzystości publicznej i odpowiedzialności prawnej. Certyfikat B Corp przyznaje organizacja pozarządowa B Lab na 3 lata, opierając się na szczegółowej weryfikacji modelu biznesowego i funkcjonowania firmy w odniesieniu do wpływu na otoczenie w obszarach, takich jak: ład korporacyjny, pracownicy, społeczeństwo i społeczności lokalne oraz środowisko naturalne (B Lab 2021g).

Aby otrzymać certyfikat B Corporation, firma musi (B Lab 2021d):

- dokonać samooceny z wykorzystaniem bezpłatnej platformy internetowej B Impact Assessment (BIA), która zawiera ok. 200 pytań dobieranych pod względem wielkości firmy, sektora i rynku (B Lab 2021g) i uzyskać minimum 80 pkt $^{1}$ (z 200 możliwych do zdobycia) (B Lab 2021e);

- przejść pozytywnie przegląd oceny (w tym dokumentów firmy) i weryfikację dokonywaną przez B Lab;

- przyjąć prawne zobowiązanie, że równorzędnym dla celu biznesowego jest cel społeczny poprzez zmianę swojego statutu, formy prawnej, lub wprowadzając inne zmiany struktury (B Lab 2021f), co zagwarantuje, że firma będzie realizowała swoją misję;

- podpisać Deklarację Współzależności jako zobowiązanie do przestrzegania wartości B Corp oraz współpracy w ramach tej społeczności (B Lab 2021b);

- wnieść opłatę certyfikacyjną, zależną od rozmiaru i lokalizacji (B Lab 2021d);

- udostępnić raport wpływu na swoim profilu na stronie internetowej B Lab (B Lab 2021e).

W tabeli 2. dokonano syntetycznego podsumowania, w jaki sposób ruch B Corp wpisuje się w paradygmat ZR i pokazuje, że uwzględnia on zarówno sprawiedliwość wewnątrz-, jak i międzygeneracyjną oraz trzy klasyczne wymiary ZR.

Analizy B Lab pokazują, że w porównaniu z przeciętnymi przedsiębiorstwami B Corps są m.in. o $87 \%$ bardziej skłonne do

1 Najlepsze B Corp uzyskują 130-140 pkt, średni zaś wynik to ok. 90-10o pkt (Kampania 17 Celów 2019). 
Tab. 2. Wpisanie ZR w założenia ruchu B Corporation

\begin{tabular}{lccc}
\hline & Deklaracja Współzależności & B Impact Assessment(BIA) & Prawne zobowiązanie \\
\hline Sprawiedliwość wewnątrzgeneracyjna & $\sqrt{ }$ & \\
\hline Sprawiedliwość międzygeneracyjna & $\sqrt{ }$ & & \\
\hline Wymiar ekonomiczny & & $\sqrt{ }$ \\
\hline Wymiar społeczny & & $\sqrt{ }$ \\
\hline Wymiar środowiskowy & $\sqrt{ }$ & \\
\hline
\end{tabular}

Źródło: opracowanie własne na podstawie strony domowej B Lab

monitorowania, rejestrowania i wyznaczania celów redukcji emisji gazów cieplarnianych, o $43 \%$ - do opłacania pracownikom ubezpieczenia zdrowotnego, o 20\% - do zapewniania elastycznego czasu pracy oraz mają o $9 \%$ bardziej różnorodne zespoły (B Lab 2021h). Na świecie ruch B Corp tworzy obecnie 3821 firm reprezentujących 150 branż i 74 państwa (B Lab 2021a), najliczniej USA i Kanadę, w Europie - Wielką Brytanię, Włochy, Holandię i Francję (Kampania 17 Celów 2019). Do B Corp należą m.in. uznawane za liderów ZR (The GlobeScan-SustainAbility Survey 2019) Patagonia, Natura i Danone. Ponadto około 100 tys. firm korzysta z narzędzia BIA, aby zarządzać swoim wpływem na otoczenie (B Lab 2021h), co pozwala mieć nadzieję, że zdecydują się w przyszłości na przystąpienie do ruchu.

\section{B Corp w Polsce}

Pierwszą firmą w Polsce (i w Europie Środkowo-Wschodniej), która w 2018 r. uzyskała certyfikat B Corp, był Benefit Systems (z BIA na poziomie 80,1), po nim do ruchu dołączyły: Netguru (w 2020 r. z BIA 81,9) i Grupa ANG S.A. (2020 r. i BIA 93,1) (B Lab 2021a). Na stronie B Lab do grona polskich firm zaliczana jest jeszcze Pixellu, firma oferująca oprogramowanie dla fotografów ślubnych (B Lab 2021c), i to jako najstarszy z polskich B Corps (od 2015 r.). Firma ta jednak jako swoje główne miejsce lokalizacji podaje Seattle, nie jest także uwzględniana na polskiej stronie B Corps, co więcej - nie chwali się certyfikatem na swojej stronie internetowej. Z kolei na polskiej stronie B Corps można znaleźć informację, że w Polsce ruch tworzy 7 firm (a kolejne 100 jest w procesie certyfikacji), przy czym dane te nie uwzględniają działających na polskim rynku zagranicznych B Corps (B Market Explorer Poland 2021). Oprócz wspomnianych firm na polskiej stronie wymieniona jest jeszcze Too Good to Go, firma oferująca aplikację pozwalającą konsumentom „uratować” paczki-niespodzianki z punktów gastronomicznych, dzięki czemu żywność nie ulega zmarnowaniu (a więc o modelu biznesowym, z założenia wspierającym cel 2. i 13.). W analizach prowadzonych na potrzeby niniejszego artykułu uwzględnione zostały tylko firmy wymienione zarówno na globalnej, jak i polskiej stronie B Corp, tj: Benefit Systems, Netguru i Grupa ANG S.A.

W tabeli 3. przedstawiono wpływ analizowanych firm na SDGs najbardziej narażone na pandemię, dodatkowo uwzględniając cel 13. dotyczący klimatu (ponieważ pozytywny wpływ pandemii na ten cel jest jedynie krótkotrwały, a kryzys klimatyczny jest najważniejszym globalnym wyzwaniem) (GlobeScan-SustainAbility Survey 2020, 10-11; Kantar, GfK 2019, 3-4). W tabeli nie uwzględniono celu 1. i 2. (dotyczących ubóstwa i głodu), ponieważ nie zidentyfikowano działań świadczących o tym, że analizowane firmy przyczyniają się do realizacji tych celów. Ze względu na ograniczoność danych dostępnych na stronach internetowych firm (w tym w umieszczonych tam dokumentach) w tabeli pominięto wskaźniki, skupiając się na generalnym wkładzie firm na rzecz ZR w ramach poszczególnych SDGs. W przypadku Netguru, firmy doradczej, projektującej produkty cyfrowe „pozwalające robić rzeczy inaczej" (Netguru 2021), zaprezentowano także wybrane projekty dla klientów. 


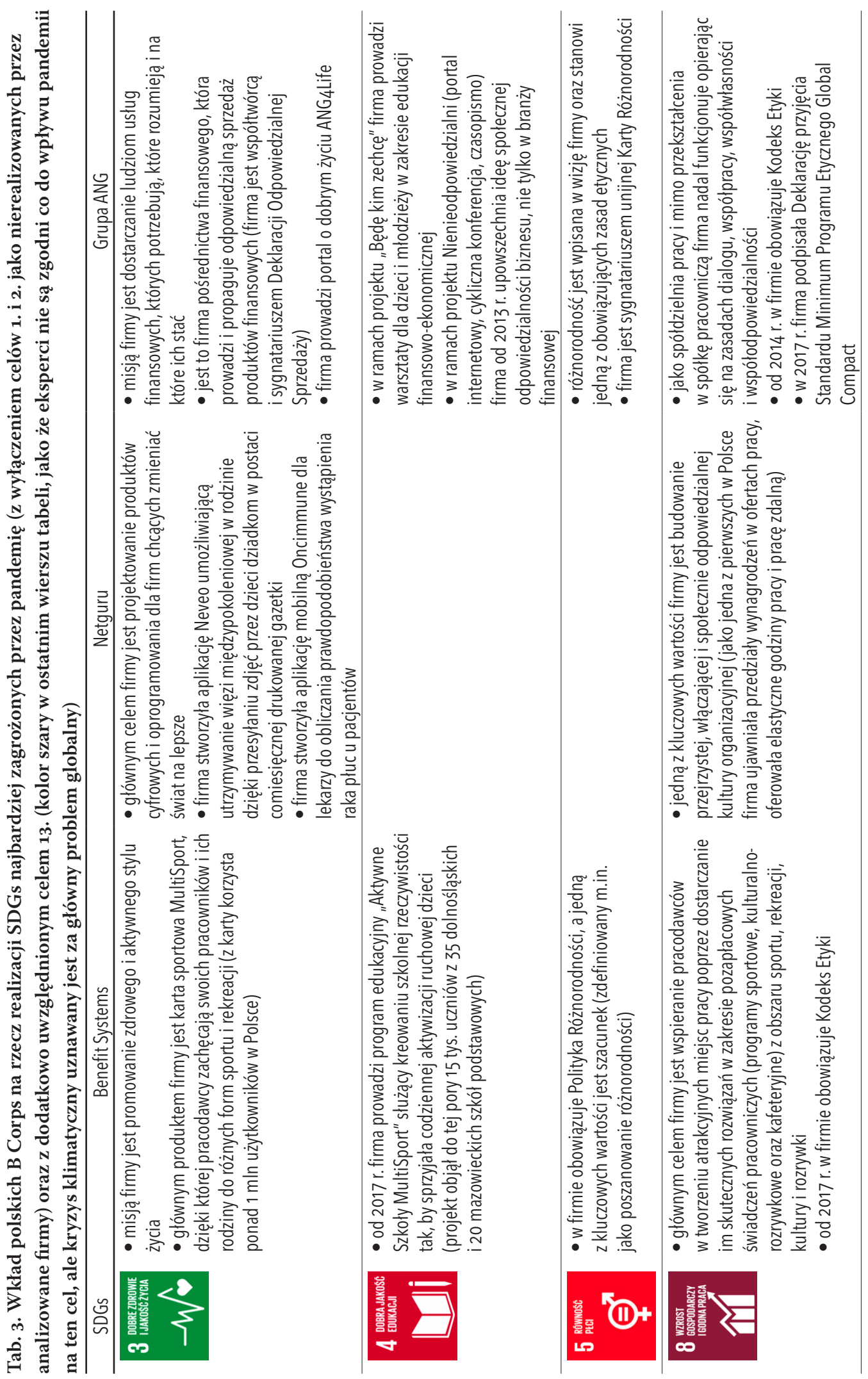




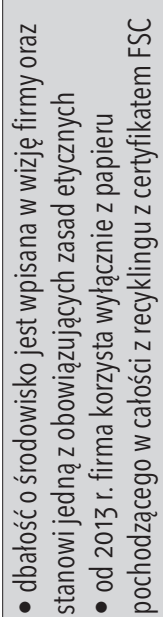

言

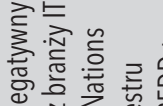

든 $\frac{10}{2}$

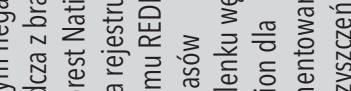

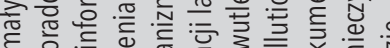

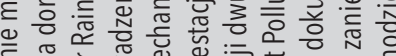

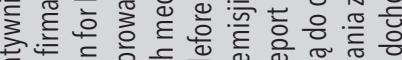

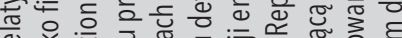

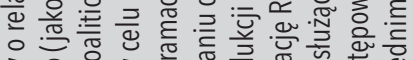

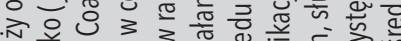

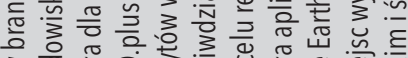

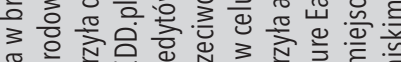

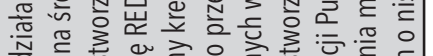

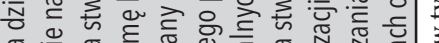

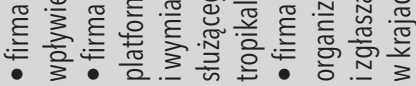

紊芯

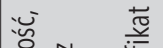

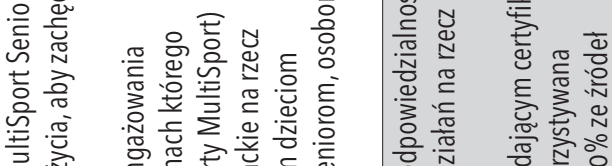

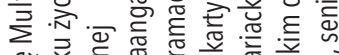

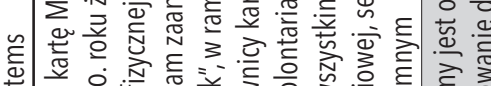

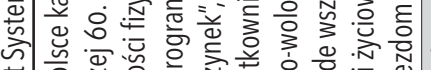

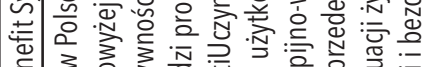


Nawet analiza dokonana na tak ograniczonej próbie pozwala stwierdzić, że B Corps to najczęściej firmy małe i średnie, które mają wpisany ZR w swoje DNA i powstały z myślą o wywieraniu pozytywnego wpływu na otoczenie (wyraźnie to widać przy przeglądaniu globalnej bazy B Corps). Warto także zauważyć, że badane firmy przyczyniają się do realizacji tych SDGs, które są szczególnie ważne w dobie pandemii, i nie są to działania ad hoc, podjęte w odpowiedzi na COVID-19, tylko zainicjowane już wcześniej i wynikające z modelu biznesowego (misji, wartości, oferowanych produktów). Odpowiedzialne doradztwo finansowe w czasie recesji, wspieranie aktywności fizycznej po miesiącach lockdownu czy projektowanie pionierskiego oprogramowania podczas cyfrowej transformacji to działania, które gwarantują, że pozytywny wpływ analizowanych firm na ZR w popandemicznej rzeczywistości będzie długofalowy.

\section{Zakończenie}

Kristalina Georgieva, dyrektor zarządzająca Międzynarodowym Funduszem Walutowym, stwierdziła, że pandemia spowodowała globalny kryzys, jakiego jeszcze nie było, który wymaga adekwatnej globalnej odpowiedzi ("a global crisis like no other needs a global response like no other") (Georgieva 2020). Chociaż trwająca cały czas pandemia uniemożliwia dokładne oszacowanie jej wielowymiarowych skutków, zwłaszcza długofalowych, wielu ekspertów jest zgodnych, że COVID-19 negatywnie wpłynie na realizację SDGs, zawracając nas z drogi ku ZR (Patrick 2020; UNDESA 202ob), czego dowodzić może spadek HDI do poziomu z lat 90. XX wieku (CCSA 2020, 38-39). Do najbardziej zagrożonych przez pandemię SDGs eksperci zaliczają cel 1. (dotyczący ubóstwa), 3. (dobrego zdrowia i jakości życia), 8. (wzrostu gospodarczego i godnej pracy) oraz 10. (nierówności), w dalszej kolejności cel dotyczący dobrej jakości edukacji (4.) oraz nierówności płci (5.) (UNDESA 202ob; UNIDO 2020a; UNSDG 2020; UNDP 2020; Sachs et al. 2020).
Biznes, ze względu na kluczową rolę jaką pełni we współczesnym świecie, jest postrzegany jako interesariusz, który ma obowiązek i możliwości, aby włączyć się w realizację SDGs, zwłaszcza gdy negatywny wpływ pandemii COVID-19 na ZR pokazał, że realizacja tej koncepcji stała się jeszcze pilniejsza. W praktyce funkcjonuje wiele koncepcji, które zawierają wytyczne dla biznesu, jak urzeczywistniać ZR w codziennym funkcjonowaniu. Jedną $\mathrm{z}$ nich jest powstały w 2006 r. ruch B Corporation.

Idea ZR jest wpisana w założenia B Corps, ponieważ misją ruchu jest wykorzystywanie siły biznesu do działania na rzecz wspólnego dobra wszystkich interesariuszy. Aby to zagwarantować, certyfikacja B Corp obejmuje nie tylko podpisanie Deklaracji Współzależności i prawne zobowiązanie do uwzględnienia celu społecznego, lecz także dokonywany co 3 lata przegląd firmy w obszarze ładu korporacyjnego, pracowników, społeczeństwa i społeczności lokalnej oraz środowiska, z którego firma musi uzyskać co najmniej minimalną liczbę punktów, przechodząc weryfikację B Lab. Chociaż założenia ruchu sprzyjają maksymalizacji wkładu na rzecz ZR, to skala ruchu (3821 firm) sprawia, że trudno mówić o globalnym, znaczącym oddziaływaniu.

W Polsce ruch B Corporation tworzy na razie tylko 7 firm, w tym Benefit Systems, Netguru i Grupa ANG S.A. Analiza trzech wymienionych firm pozwoliła stwierdzić, że poprzez swoją działalność przyczyniają się one do realizacji tych SDGs, które w dobie pandemii są szczególnie ważne, a zrównoważony rozwój jest rzeczywiście wpisany w ich modele biznesowe - od misji i wizji, poprzez wartości, aż do oferowanych produktów i codziennych działań, w tym na rzecz pracowników i otoczenia.

W ogłoszonym w październiku $2018 \mathrm{r}$. specjalnym raporcie Międzyrządowy Zespół ds. Zmian Klimatu (Intergovernmental Panel on Climate Change, IPCC) stwierdził, że aby ograniczyć globalne ocieplenie do 2050 r., konieczne są transformacyjne i systemowe zmiany na szeroką skalę i we 
wszystkich dziedzinach życia (IPCC 2018). Pandemia zburzyła stary porządek, pierwszy zatem krok ku rewolucji został już poczyniony. Ruch B Corporation podpowiada, jak powinien wyglądać biznes w popandemicznej rzeczywistości, jednak by można mówić o zmianie, konieczne jest upowszechnienie tego sposobu działania.

\section{Bibliografia}

Amante, Angelo, and Crispian Balmer. 2020. "Why has Italy suffered so badly during the pandemic?" Accessed March 9, 2021. www.weforum.org/ agenda/2020/12/italy-death-toll-pandemic-covid-coronavirus-health-population-europe/.

B Lab. 2021a. "A Global Community of Leaders." Accessed March 9, 2021. https://bcorporation.net/.

B Lab. 2021b. "About B Corps." Accessed March 5, 2021. https://bcorporation.net/about-b-corps.

B Lab. 2021c. "B Impact Report. Pixellu." Accessed March 9, 2021. https://bcorporation.net/directory/ pixellu.

B Lab. 2021d. “Certification.” Accessed March 5, 2021. https://bcorporation.net/certification.

B Lab. 2021e. "Certification Requirements." Accessed March 9, 2021. https://bcorporation.net/ certification/meet-the-requirements.

B Lab. 2021f. "Legal Requirements." Accessed March 9, 2021. https://bcorporation.net/certification/ legal-requirements.

B Lab. 2021g. "The B Impact Assessment." Accessed March 9, 2021. https://bimpactassessment. net/?_ga=2.192882665.29009165.16153701511263816775.1614939266.

BLab.2021h. "WelcomeGuide."AccessedMarch 9,2021. https://pardot.bcorporation.net/b-corp-welcomeguide?_ga=2.180244199.29009165.16153701511263816775.1614939266.

B Market Explorer Poland. 2021. "B Corpy w Polsce.” Dostęp 9.03.2021. https://bcorp.pl/ polskie-b-corpy/.

Bremmer, Ian. 2021. "The Best Global Responses to the COVID-19 Pandemic, 1 Year Later." Accessed March 9, 2021. https://time.com/5851633/ best-global-responses-covid-19/.

CCSA. 2020. "How COVID-19 is changing the world: a statistical perspective." Accessed March 9, 2021. https://unstats.un.org/unsd/ccsa/documents/covid19-report-ccsa.pdf.
Chriscaden, Kimberly. 2020. "Impact of COVID-19 on people's livelihoods, their health and our food systems. Joint statement by ILO, FAO, IFAD and WHO." Accessed March 9, 2021. www.who.int/ news/item/13-10-2020-impact-of-covid-19-onpeople's-livelihoods-their-health-and-our-foodsystems.

Copenhagen Economics. 2020. "Economic consequences of the Covid-19 pandemic." Accessed March 9, 2021. www.copenhageneconomics. $\mathrm{com} /$ dyn/resources/Publication/publicationPDF/0/530/1585835646/copenhagen-economics_economic-consequences-covid-19.pdf.

Crane, Andrew, Matten, Dirk, and Jeremy Moon. 2008. "The Emergence of Corporate Citizenship: Historical Development and Alternative Perspectives." In Handbook of Research on Corporate Citizenship, edited by Andreas Georg Scherer and Guido Palazzo, 25-49. Cheltenham: Edward Elgar Publishers.

de Castro Sobrosa Neto, Ruy, Janayna Sobrosa Maia, Samara de Silva Neiva, Michael Dillon Scalia, and Jose Baltazar Salgueirinho Osório de Andrade Guerra. 2020. "The fourth industrial revolution and the coronavirus: a new era catalyzed by a virus." Research in Globalization 2: 100024. https:// doi.org/10.1016/j.resglo.2020.100024.

Deloitte. 2020. „Aż 91 proc. członków kadry kierowniczej odczuwa wpływ zmian klimatu na funkcjonowanie ich biznesu." Dostęp 9.03.2021. https:// www2.deloitte.com/pl/pl/pages/press-releases/ articles/biznes-a-zmiany-klimatu.html.

ECDC. 2021. "Risk Assessment: Risk related to the spread of new SARS-CoV-2 variants of concern in the EU/EEA - first update." Accessed March 9, 2021. www.ecdc.europa.eu/en/publications-data/ covid-19-risk-assessment-spread-new-variantsconcern-eueea-first-update.

Edelman. 2021. "Edelman Trust Barometer 2021. Global Report." Accessed March 9, 2021. www.edelman.com/sites/g/files/aatuss191/ files/2021-01/2021-edelman-trust-barometer.pdf. EIGE. 2021. "The Covid-19 pandemic and intimate partner violence against women in the EU." Accessed March 9, 2021. https://eige.europa. $\mathrm{eu} /$ sites/default/files/documents/20210224_ mhna30566enn_pdf.pdf. 
Elkington, John. 1997. Cannibals with Forks: Triple Bottom Line of 21st Century Business. Oxford: Capstone Publishing Limited.

FAO. 2020. "The State of Food Security and Nutrition in the World 2020." Accessed March 9, 2021. www. fao.org/3/ca9692en/ca9692en.pdf.

Georgieva, Kristalina. 2020. "A Global Crisis Like No Other Needs a Global Response Like No Other." Accessed March 9, 2021. https://blogs. imf.org/2020/04/20/a-global-crisis-like-no-otherneeds-a-global-response-like-no-other/.

Graves, Ginny. 2021. "What Is Post-COVID Syndrome? Doctors Explain Why It Causes Extreme Symptoms in Long-Haulers." Accessed March 9, 2021. www.prevention.com/health/a35218558/ what-is-post-covid-syndrome/.

Green Recovery Alliance. 2020. "REBOOT \& REBOOST our economies for a sustainable future. Call for mobilization." Accessed March 9, 2021. https://drive.google.com/file/d/ 1j54QxE-QjhrEHjGb5LrKsHuDAKvv8LUq/ view.

Hiscott, John, Magdalini Alexandridi, Michela Muscolini, Evelyne Tassone, Enrico Palermo, Maria Soultsioti, and Alessandra Zevini. 2020. "The global impact of the coronavirus pandemic." $\mathrm{Cy}$ tokine E Growth Factor Reviews 53: 1-9. https:// doi.org/10.1016/j.cytogfr.2020.05.010.

Hopwood, Bill, Mary Mellor, and Geoff O’Brien. 2005. "Sustainable Development: Mapping Different Approaches". Sustainable Development 13: 38-52. https://doi.org/10.1002/sd.244.

IMF. 2020. "World Economic Outlook. The Great Lockdown.” Accessed March 9, 2021. www.imf. org/-/media/Files/Publications/WEO/2020/April/ English/text.ashx.

IPCC. 2018. "Global Warming of $1,5^{\circ} \mathrm{C}$. Special report.” Accessed March 9, 2021. www.ipcc.ch/sr15/.

Kampania 17 Celów. 2019. „Certyfikacja B Corp. Forum Inspiracji, Warszawa 17 maja 2019 r.” Dostęp 9.03.2021. https://kampania17celow.pl/wp-content/uploads/2019/05/Certyfikacja-B-Corp-Benefit-Systems-Forum-Inspiracji-2019.pdf.

Kantar, GfK. 2019. "Who cares, who does? Consumer response to plastic waste." Accessed March 9, 2021. https://bioplasticsnews.com/wp-content/ uploads/2019/09/Kantar-Who-Cares-Who-DoesSept2019.pdf.
Koprowska, Joanna. 2020. „Czas próby dla kobiet. Raport: kobiety w biznesie." ICAN Management Review Polska 6. Dostęp 9.03.2021. www.ican.pl/a/ czas-proby-dla-kobiet/DkNyuYcne.

Kramer, Mark R., and Michael E. Porter. 2011. „Tworzenie wartości dla biznesu i społeczeństwa." Harvard Business Review Polska 99: 36-57.

Laloux, Frederic. 2015. Pracować inaczej. Nowatorski model organizacji inspirowany kolejnym etapem rozwoju ludzkiej świadomości. Warszawa: Studio EMKA.

Lélé, Sharachchandra M.. 1991. "Sustainable Development. A Critical Review." World Development 19(6): 607-621.

Mensah, Justice, and Sandra Ricart Casadevall (Reviewing editor). 2019. "Sustainable development: Meaning, history, principles, pillars, and implications for human action: Literature review." Cogent Social Sciences 5: 1. https://doi.org/10.1080/23311 886.2019.1653531.

Ministerstwo Zdrowia. 2020. „Pierwszy przypadek koronawirusa w Polsce." Dostęp 9.03.2021. www.gov.pl/web/zdrowie/ pierwszy-przypadek-koronawirusa-w-polsce.

Mordecai, Mara, and Shannon Schumacher. 2020. "In many countries, people are more negative about the economy amid COVID-19 than during Great Recession." Accessed March 9, 2021. www.pewresearch.org/fact-tank/2020/09/14/ in-many-countries-people-are-more-negativeabout-the-economy-amid-covid-19-than-duringgreat-recession/.

Netguru. 2021. "Netguru Team." Accessed March 9, 2021. www.netguru.com/about-us/team-netguru. OECD. 2020. "Release of the June 2020 Economic Outlook: Revamping the international policy architecture to emerge from the pandemic stronger together." Accessed March 9, 2021. www.oecd.org/ about/secretary-general/release-of-the-june-2020economic-outlook.htm.

ONZ. 1972. "Report of the United Nations Conference on the Human Environment." Stockholm.

ONZ. 1992. "United Nations Conference on Environment \& Development, Rio de Janerio, Brazil, 3 to 14 June 1992. AGENDA 21."

ONZ. 2015. „Rezolucja przyjęta przez Zgromadzenie Ogólne w dniu 25 września 2015 r. Przekształcamy nasz świat: Agenda na rzecz zrównoważonego rozwoju 2030." Dostęp 9.03.2021. www.unic.un.org. 
pl/files/164/Agenda\%202030_pl_2016_ostateczna. pdf.

Panchal, Nirmita, Rabah Kamal, Cynthia Cox, and Rachel Garfield. 2021. "The Implications of COVID-19 for Mental Health and Substance Use." Accessed March 9, 2021. www.kff.org/coronavirus-covid-19/issue-brief/the-implications-ofcovid-19-for-mental-health-and-substance-use/.

Patrick, Stewart M. 2020. "Another Victim of COVID-19: Sustainable Development.” Accessed March 9, 2021. www.worldpoliticsreview.com/ articles/28732/another-victim-of-covid-19-sustainable-development.

PKN. 2012. Norma PN-ISO26000. Wytyczne dotyczace społecznej odpowiedzialności. Warszawa: PKN.

Reilly, John M., Y.-H. Henry Chen, and Henry D. Jacoby. 2021. "The COVID-19 effect on the Paris agreement." Humanities and Social Sciences Communication 8(16). https://doi.org/10.1057/ s41599-020-00698-2.

Sachs, Jeffrey, Guido Schmidt-Traub, Christian Kroll, Guillaume Lafortune, Grayson Fuller, and Finn Woelm. 2020. “The Sustainable Development Goals and COVID-19. Sustainable Development Report 2020." Cambridge: Cambridge University Press. Accessed March 9, 2021. https:// s3.amazonaws.com/sustainabledevelopment.report/2020/2020_sustainable_development_report.pdf.

The GlobeScan-SustainAbility Survey. 2019. “The 2019 Sustainability Leaders." Accessed March 9, 2021. https://globescan.com/wp-content/uploads/2019/07/GlobeScan-Sustain Ability-Leaders-Survey-2019-Report.pdf.

The GlobeScan-SustainAbility Survey. 2020. "The 2020 Sustainability Leaders.” Accessed March 9, 2021. www.sustainability.com/contentassets/ b298c9248bd14c03951e8801a6880436/gss-leaders-report-2020.pdf.

The Lancet. 2021. "Climate and COVID-19: converging crises.” The Lancet 397(10269): 71. https://doi. org/10.1016/S0140-6736(20)32579-4.

The World Bank. 2021. "Understanding the Coronavirus (COVID-19) pandemic through data." Accessed March 9, 2021. https://datatopics.worldbank.org/ universal-health-coverage/coronavirus/.

UNDESA. 2020a. "UN/DESA Policy Brief \#81: Impact of COVID-19 on SDG progress: a statistical perspective." Accessed March 9, 2021. www. un.org/development/desa/dpad/publication/undesa-policy-brief-81-impact-of-covid-19-on-sdgprogress-a-statistical-perspective/.

UNDESA. 2020b. "World Economic Situation And Prospects: April 2020 Briefing, No. 136." Accessed March 9, 2021. www.un.org/development/ desa/dpad/publication/world-economic-situation-and-prospects-april-2020-briefing-no-136/.

UNDP. 2020. "Brief \#2: Putting the UN Framework for Socio-Economic Response to COVID-19 into Action: Insights." Accessed March 9, 2021. www. undp.org/content/dam/undp/library/covid19/ Brief2-COVID-19-final-June2020.pdf.

UNDP. 2021. "COVID-19 and the SDGs. How the 'roadmap for humanity' could be changed by a pandemic." Accessed March 9, 2021. https://feature. undp.org/covid-19-and-the-sdgs/.

UNGC. 2013. "Corporate Sustainability and the United Nations Post-2015 Development Agenda." Accessed March 9, 2021. https://d306pr3pise04h. cloudfront.net/docs/news_events\%2F9.1_news_archives\%2F2013_06_18\%2FUNGC_Post2015_Report.pdf.

UNIDO. 2020a. "Coronavirus: the economic impact - 26 May 2020.” Accessed March 9, 2021. www.unido.org/stories/ coronavirus-economic-impact-26-may-2020.

UNIDO. 2020b. "Coronavirus: the economic impact - 21 October 2020.” Accessed March 9, 2021. www.unido.org/stories/ coronavirus-economic-impact-21-october-2020.

UNSDG. 2020. "Shared responsibility, global solidarity: responding to the socio-economic impacts of COVID-19." Accessed March 9, 2021. https://unsdg. un.org/sites/default/files/2020-03/SG-Report-Socio-Economic-Impact-of-Covid19.pdf.

WCED. 1987. "Our Common Future." Oxford, UK: Oxford University Press.

WHO. 2020a. "SARS-CoV-2 mink-associated variant strain - Denmark." Accessed March 9, 2021. www.who.int/csr/don/06-november-2020-mink-associated-sars-cov2-denmark/ en/.

WHO. 2020b. "WHO Director-General's opening remarks at the media briefing on COVID-1911 March 2020." Accessed March 9, 2021. www. who.int/director-general/speeches/detail/ 
who-director-general-s-opening-remarks-atthe-media-briefing-on-covid-19---11-march-2020. WHO. 2021a. "Coronavirus disease (COVID-19) pandemic." Accessed March 9, 2021. www.who. int/emergencies/diseases/novel-coronavirus-2019. WHO. 2021b. "WHO Coronavirus (COVID-19) Dashboard." Accessed March 9, 2021. https:// covid19.who.int/.
Yunus, Muhammad. 2020. „Nie planujmy odtwarzania gospodarki po koronawirusie. Zaprojektujmy ją od nowa." Odpowiedzialny biznes. Kompendium CSR edycja 22.

Zimmer, Katarina. 2021. “COVID-19's Effects on the Brain." Accessed March 9, 2021. www.the-scientist.com/news-opinion/ covid-19s-effects-on-the-brain-68369. 